\title{
Constant-Current Coulometry and Ion Chromatography Bromide Determination to Characterize the Purity of the Potassium Chloride
}

\author{
Paulo P. Borges, ${ }^{*, a}$ Sidney P. Sobral, ${ }^{a}$ Lilian da Silva, ${ }^{b}$ Thiago O. Araújo ${ }^{b}$ and Renata S. Silva ${ }^{b}$ \\ ${ }^{a}$ Electrochemistry Laboratory (Label) and ${ }^{b}$ Inorganic Laboratory (Labin), Chemical Metrology Division - \\ National Institute of Metrology, Standardization and Industrial Quality (Inmetro), \\ Av. Nossa Senhora das Graças, 50, Prédio 4, Xerém, 25250-020 Duque de Caxias-RJ, Brazil
}

\begin{abstract}
A coulometria é considerada o método de maior qualidade metrológica para medição de quantidade de substância de padrões primários. Entretanto, a contaminação de sais de elevada pureza está presente em níveis traços sendo necessária a sua identificação e quantificação. Este trabalho apresenta os estudos desenvolvidos pelo Inmetro (Instituto Nacional de Metrologia, Normalização e Qualidade Industrial, Brasil) para determinar a pureza do cloreto de potássio $(\mathrm{KCl})$ por titulação coulométrica a corrente constante, além da determinação do brometo como seu principal contaminante por cromatografia iônica (IC). Esses estudos foram necessários para desenvolver material de referência certificado (MRC) de $\mathrm{KCl}$ para garantir a qualidade dos resultados das medições químicas principalmente as de titulometria. A caracterização do candidato a MRC de $\mathrm{KCl}$ apresentou pureza de $99,9662 \%$, a qual foi obtida após a correção do brometo, em fração mássica, obtido por IC, de 182,47 $\pm 3,03 \mathrm{mg} \mathrm{kg}^{-1}$ (incerteza expandida, $k=2$, para um nível de confiança de aproximadamente de $95 \%$ ).
\end{abstract}

Coulometry is considered the highest metrological method for measuring the amount of substance of high-purity compounds. However, the contamination of the high purity salts is present in trace levels and its identification and quantification are necessary. This work aims to present the studies performed by Inmetro (National Institute of Metrology, Standardization and Industrial Quality, Brazil) to determine the purity of potassium chloride $(\mathrm{KCl})$ by constant-current coulometric titration, as well as the determination of bromide as the main impurity in the $\mathrm{KCl}$ through ion chromatography (IC). These studies were needed to develop certified reference material (CRM) of $\mathrm{KCl}$ to guarantee the quality of the chemical measurements, mainly those performed by titrimetric analysis. The characterization of the candidate $\mathrm{CRM}$ of $\mathrm{KCl}$ by coulometric titration presented the purity of $99.9662 \%$. This value was obtained after bromide correction of $182.47 \pm 3.03 \mathrm{mg} \mathrm{kg} \mathrm{kg}^{-1}$ (expanded uncertainty for $k=2$, for a confidence level of approximately $95 \%$ ) for the mass fraction bromide assayed by IC.

Keywords: coulometry, ion chromatography, potassium chloride, bromide, certified reference material

\section{Introduction}

The potassium chloride is an essential vegetable nutrient used as a fertilizer and also an important chemical reagent used in large scale in chemical and pharmaceutical industries for various purposes. The purity required for most of these applications is about $98 \% .^{1}$ The salt is used in various types of industrial products such as inks, soaps, detergents, foodstuffs, pharmaceuticals, as well as raw material for the preparation of other chemical substances

*e-mail: ppborges@inmetro.gov.br such as potassium hydroxide and potassium carbonate. In addition, it is research foundation for $\mathrm{pH}$, electrolytic conductivity and mono-element standard solutions. ${ }^{2}$

Metrology in chemistry has been currently acknowledged as a relevant area in researches of analytical and measuring chemistry. Its importance comes from the need to produce reliable and uniform measurements in science, technology and international trade. ${ }^{3}$ In the analytical chemistry area, a great number of methods uses titration as the main technique to determine the concentration of a substance in a specific analyte. In order to carry out this analysis with accuracy, the laboratories need to use primary standards..$^{4,5}$ 
However, the primary standards should have properties such as high purity and homogeneity, definitely stable, precise composition, ability to give a thorough, simple and stoichiometric reaction with a titrant, easy to dry and handle. ${ }^{6,7}$

One of the main functions of a National Metrology Institute (NMI) is to certify primary standards, e.g. to determine the purity of primary reference materials in order to develop the certified reference materials (CRMs). Inmetro (National Institute of Metrology, Standardization and Industrial Quality), the NMI of Brazil, aims to ensure traceability and reliability to the purity of salts, promoting the improvement of the quality of products and thus, the competitiveness of Brazilian industries.

Coulometric methods are capable of high precision and accuracy and are totally described by Faraday's law. ${ }^{8}$ Coulometry is considered to have the potential to become a primary method ${ }^{9}$ by the Consultative Committee for Amount of Substance (CCQM), Metrology in Chemistry. Inmetro has established a primary system of coulometry ${ }^{10}$ in its Electrochemistry Laboratory (Label) to characterize and certify high-purity reference materials such as primary standards in order to guarantee the reliability of the chemical analysis performed by Brazilian laboratories. These reference materials can be used as primary standards in acid/base, precipitation, redox and complexometric titration techniques ${ }^{11-13}$ to determine the concentration of diverse chemical substances.

Judging by the analysis of the $\mathrm{KCl},{ }^{14}$ the main substance considered by the authors as an impurity to this work was bromide $(0.05 \%)$. During the coulometric titration of the $\mathrm{KCl}$, bromide ions are titrated indifferently as chloride ions. Therefore, the final result (which is related only to the concentration of chloride ion) would be over evaluated if both the titrations of the bromide ions and the chloride ions in the salt are considered. Hence, due to the electrochemical activity of the bromide ions, they should be analyzed with accuracy by using a sensitive and selective technique in order to be considered as impurity in the characterization of the candidate CRM of $\mathrm{KCl}$ by coulometric titration. The selected technique was ion chromatography (IC) using ion-exchange separation mode coupled with a membrane suppressed conductivity detector without sample pretreatment. The final result will then be considered as $100 \%$ of the concentration value obtained by coulometry minus the value of bromide concentration obtained from IC.

Ion chromatography with electrochemical detection has been preferred at times since it has been used for the determination of trace anions, including bromide, with conductivity detection..$^{15-17}$ However, the column is overloaded when the chloride concentration is very large (which is often present as a 100-fold excess in environmental samples) interfering in the elution for being very close to the bromide, ${ }^{18}$ and thus making the bromide quantification impossible when implementing common elutes like carbonate or borate buffers. ${ }^{19}$ Bicarbonate eluents (also mixed carbonate-bicarbonate eluents) have been used as the mainstay of IC for many years. The problem with these eluents is that the carbonic acid formed after suppression is susceptible to partial dissociation, leading to a background conductance that is somewhat higher than desired. ${ }^{20}$ Sodium carbonate is considered as an inorganic additive and its presence in the mobile phase influences the analytes retention times $^{21}$ and causes unstable baselines in the chromatograms. ${ }^{20}$ The ideal eluent is hydroxide since it forms water after suppression which has virtually zero conductance and therefore provides the perfect conductivity baseline. ${ }^{20}$

This work aims at presenting the studies which have been developed using the primary system of coulometry from Inmetro to characterize primary standards. For determining the purity of a $\mathrm{KCl}$ sample, coulometric titration was used to determine all the chloride contained in the sample as well as bromide determination as the main impurity through ion chromatography. The final result was obtained by the difference between the total chlorides from coulometric titration and the total bromides determined by ion chromatography. Initially, the preliminary studies will be shown to determine the purity of potassium chloride $(\mathrm{KCl})$ using a standard reference material (SRM) from the National Institute of Standard and Technology (NIST). Then, there will be a focus on the results of an international comparison organized by CCQM to test the abilities of the metrology institutes to measure the amount content of chloride in $\mathrm{KCl}$, called CCQM-K48. Finally, the characterization of the purity of $\mathrm{KCl}$ from a candidate CRM will be shown.

\section{Experimental}

\section{Coulometric analysis}

\section{Coulometric titration procedure for $\mathrm{KCl}$ assay}

The primary system of coulometry from Inmetro consists of equipment of higher metrological quality (higher stability, sensibility and precision). All the equipment that constitutes the coulometric system was published elsewhere. ${ }^{10}$

For determining the purity of $\mathrm{KCl}$, the constant-current coulometric titration was used. In high-precision constantcurrent coulometry, charge is added in three stages..$^{10,13,22} \mathrm{In}$ the initial titration (pretitration), a small amount of analyte (spike) is added, and small charge increments at low current 
are used to locate the initial end point. The electrolyte is then prepared (without impurities) for the second titration called main titration, where the sample is added and $99.95 \%$ of the electrochemistry reaction is carried out by using higher current than the initial titration. In the final titration, the process is ended where the end point for the titration of the sample is detected, using small charge increments as in the initial titration. By Faraday's law, the charge consumed between the two end points is equivalent to the amount of the sample. The measurement equation is shown below as equation 1 :

$v=\frac{I_{1}\left(t_{1}-\operatorname{cor}_{1}\right)+I_{2} t_{2}+I_{3} t_{3}}{z \mathrm{~F} \mathrm{mcor}}$

where, $v=$ amount content, $I_{1}=$ current during the initial titration, $I_{2}=$ current during the main titration, $I_{3}=$ current during the final titration, $t_{1}=$ total time of initial titration from the initial end-point, $t_{2}=$ time of the main titration, $t_{3}=$ total time of final titration up to the final end-point, $z=$ charge number of the analyte, $\mathrm{F}=$ Faraday constant $\left(96485.3383 \mathrm{C} \mathrm{mol}^{-1}\right), \mathrm{m}=$ sample weight, cor $=$ sample weight to air buoyancy correction and cor $_{1}=$ correction of the difference between the end point and time of filling the intermediate compartment of the cell.

The end-point detection was carried out by using the potentiometric technique with glass and silver-silver chloride electrodes. The end points were measured by non-linear regression analysis of the titration curves. The sample of $\mathrm{KCl}$ was dried in a muffle furnace at $500{ }^{\circ} \mathrm{C}$ for $6 \mathrm{~h}$ without crushing or grinding. After, it was placed in desiccator with silica gel to be cooled. The coulometric glass cell had a vertical design with two separate compartments: a cathodic and an anodic one. The cathodic compartment was inside an intermediate compartment which was separated from the anodic one through a silicate plug. The supporting electrolyte $(250 \mathrm{~mL})$ was a solution of $3.5 \mathrm{~mol} \mathrm{~L}^{-1}$ of perchloric acid (Merck, 70-72\%). In perchloric acid, the current efficiency is close to $100 \%$ for current densities up to $100 \mathrm{~mA} \mathrm{~cm}{ }^{-2} .{ }^{23}$ Whenever not mentioned, a high purity silver rod $(99.999 \%)$ was the anode with an initial area of $c a .8 \mathrm{~cm}^{2}$. Pt electrode $\left(1 \mathrm{~cm}^{2}\right.$ area) was the cathode. The necessary current for the coulometric titration of $\mathrm{KCl}$ sample (weighing on the range of $300 \mathrm{mg}$ by using a microbalance, Mettler Toledo, UMX 5, resolution of $0.1 \mu \mathrm{g}$ ) passed through 3 different stages: in the initial titration, it was passed a current of $10 \mathrm{~mA}$; in the main titration, a current of $200 \mathrm{~mA}$ and for the final titration, $10 \mathrm{~mA}$. All the weighing was corrected for buoyancy and the coulometric cell was maintained at $23^{\circ} \mathrm{C}$ during the experiment. Firstly, argon gas of high purity
(99.999\%) was passed through the anodic compartment for deaeration. After, it was maintained above the anolyte during the titrations. All the titrations were carried out without the presence of light (with the coulometric cell shielded) to avoid dissolving the formed precipitate as well as photochemical decomposition of silver chloride which can cause errors in the titration. ${ }^{13,18,24}$ During the whole process, the anolyte solution was magnetically stirred. Figure 1 shows the schematic diagram of the coulometric cell used to determine the $\mathrm{KCl}$ purity linked to the primary system of coulometry.

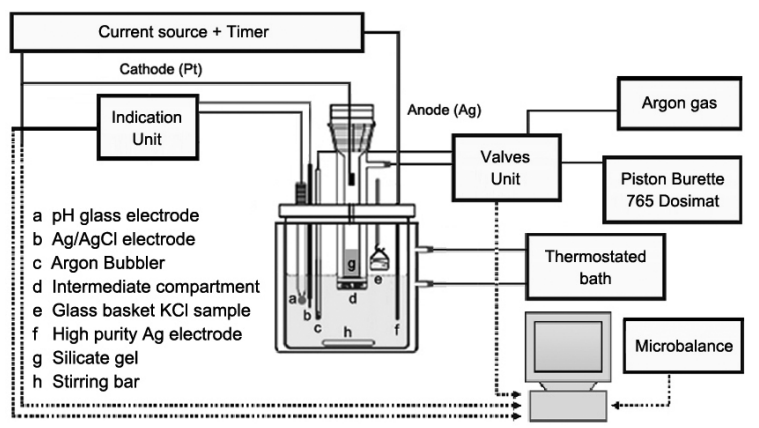

Figure 1. Schematic diagram of the coulometric cell with the primary system of coulometry from Inmetro.

\section{Ion chromatography analysis for bromide ion}

\section{Solutions and reagents}

Ultra pure water was obtained by an Elix 10 reverse osmosis system (Milli-Q gradient A10 system (Millipore, Bradford, USA)) having a minimum resistivity of $18.2 \mathrm{M} \Omega \mathrm{cm}$. This water was used to prepare all the solutions.

The calibration solutions of bromide were prepared through gravimetric dissolution of appropriate masses of the standard reference material (SRM) 3184 from NIST $^{25}$ in order to have the six calibration solutions with concentration ranging from 0.05 to $1.50 \mathrm{mg} \mathrm{kg}^{-1}$. The masses of bromide solutions were weighed in $50 \mathrm{~mL}$ capacity polypropylene (PP) flasks and completed to approximately $50 \mathrm{~g}$ in the same flasks. These solutions were prepared immediately before analysis.

\section{Equipment}

The used chromatographic system was a Dionex Model ICS 2000 equipped with an Ion Pac AS 18 analytical column and an Ion Pac AG 18 precolumn with internal diameter of $5 \mu \mathrm{m}$ and dimensions of $4 \mathrm{~mm} \times 250 \mathrm{~mm}$ and $4 \mathrm{~mm} \times 50 \mathrm{~mm}$, respectively. These columns were coupled with an ASRS ultra $4 \mathrm{~mm}$ membrane conductivity suppressor using a $99 \mathrm{~mA}$ current. A gradient pump device GS 50 was used. Sample injection volumes of $25 \mu \mathrm{L}$ were used in a system coupled with an auto sample AS40. 
The separation was based on ion exchange chromatography using an isocratic eluent generator of sodium hydroxide. The eluent generator of $\mathrm{KOH}$ coupled with a continuously regenerated trap column was used to remove trace level anionic contaminants from the carrier deionized water, as well as to protect the ion exchange columns and system components. Conductivity signals were measured by a stabilized conductivity cell DS 6 , which was controlled by an electrochemical detection module ED 50.

The chromatograms were obtained with the aid of a 6.5v Chromeleon software. Equipment and software were supplied by Dionex (Dionex Corporation, Sunnyvale, USA).

The analytical balance used to prepare all solutions was a Satorius, model ME235S, of $0.01 \mathrm{mg}$ resolution.

\section{Sample preparation}

The sample from CCQM-K48 (called in this work as unknown sample) and the quality control (QC) sample (SRM 999b) were dried at $500^{\circ} \mathrm{C}$ for $6 \mathrm{~h}$ without crushing or grinding. After being dried, they were placed in a desiccator with silica gel and cooled to room temperature before weighing it. The same procedure was used to sample preparation candidate $\mathrm{CRM}$ of $\mathrm{KCl}$.

Aliquots of the samples were taken from the bottle to the weighing flask using polytetrafluorethylene (PTFE, Teflon ${ }^{\circledR}$, DuPont) coated spatula. Two aliquots of approximately $0.5 \mathrm{~g}$ of each sample (unknown, candidate CRM and QC) were taken to $50 \mathrm{~mL}$ capacity of the polypropylene flasks for the determination of bromide. The samples were diluted gravimetrically with ultra pure water to a final mass of about $50 \mathrm{~g}$ in the same flask. The salts were weighed and then homogenized for about $1 \mathrm{~h}$. The samples were filtered using filter caps on the sample vials before introducing the chromatographic system by auto-sampler. Sixteen replicates of each aliquot were analyzed. The analyses were performed immediately after dissolution.

\section{Results and Discussion}

\section{Assay of $\mathrm{KCl}$ purity from NIST SRM}

In order to evaluate the accuracy of the results of the measurement using the primary system of coulometry from Inmetro, a constant-current coulometry technique was applied to determine the purity of potassium chloride using the SRM 999b from NIST. In Table 1, these preliminary studies related to the measurement results of the purity of the $\mathrm{KCl}$ by coulometric titrations are shown.

In Table 1, the results show good agreement with the certified value. However, considering the certified value of
Table 1. Purity of the $\mathrm{KCl}$ from SRM $999 \mathrm{~b}$ determined by coulometric titration

\begin{tabular}{lcc}
\hline$n^{\mathrm{a}}$ & Assay / $\left(\mathrm{mol} \mathrm{kg}^{-1}\right)$ & Mass fraction / \% \\
\hline 1 & 13.40705 & 99.951 \\
2 & 13.40694 & 99.951 \\
3 & 13.40695 & 99.951 \\
4 & 13.40769 & 99.956 \\
\hline Mean /\% & 99.952 \\
$\mathrm{RSD}^{\mathrm{b}} / \%$ & & 0.003 \\
\hline
\end{tabular}

${ }^{\mathrm{a}} n$, measurement; ${ }^{\mathrm{R}} \mathrm{SD}$, relative standard deviation.

SRM $999 \mathrm{~b}$ (99.977\%), which is in the NIST certificate, ${ }^{26}$ the measurement presented good precision (RSD $0.003 \%$ ), but it was $0.025 \%$ biased. Therefore, this result suggests that the measurement needs to be improved in order to increase its sensitivity as well as its accuracy. One possibility is to use a silver electrode with high purity, since in the prior analysis these assays were carried out with a silver electrode with only $99.99 \%$ purity. This may have affected the current efficiency of the coulometric process due to the presence of less noble metals which can interfere in the generation of $\mathrm{Ag}^{+}$ion. ${ }^{27}$ Other possibility may be the non consideration of the bromide ion as the main impurity in the $\mathrm{KCl} \cdot{ }^{26}$

\section{Ion chromatography of the bromide impurity in $\mathrm{KCl}$}

In this study an analytical method for the determination of bromide impurity in $\mathrm{KCl}$ salt is provided. The best method optimization was obtained by using an eluent flow rate of $1.2 \mathrm{~mL} \mathrm{~min}^{-1}$ and eluent composition of $30 \mathrm{mmol} \mathrm{L}^{-1} \mathrm{KOH}$. In these conditions, the background conductivity obtained in the detector was around $0.55 \mu \mathrm{S} \mathrm{cm}^{-1}$ and $15.7 \times 10^{3} \mathrm{kPa}(2243 \mathrm{psi})$ system pressure. A typical chromatogram of $\mathrm{KCl}$ sample using the described optimized conditions can be seen in Figure 2. The samples unknown (CCQM-K48) and candidate CRM were diluted 100 and 400 times, respectively, prior to analysis since the concentration of chloride was extremely high (about 100,000 times bigger than the bromide). Neither the resolution nor the efficiency was affected. No sample pretreatment was performed.

Analytical curves were obtained in a range between 0.05 and $1.5 \mathrm{mg} \mathrm{kg}^{-1}$ by using six calibration solutions. The correlation coefficient was better than 0.9996 and the sensitivity obtained was $0.43 \mathrm{mg} \mathrm{kg}^{-1}$.

The limit of detection (LOD) $0.1 \mu \mathrm{g} \mathrm{kg}^{-1}$ and limit of quantification (LOQ) $0.3 \mu \mathrm{g} \mathrm{kg}^{-1}$ of the method were obtained from the standard deviation of the blank curve. Eight replicates were measured and the LOD was 


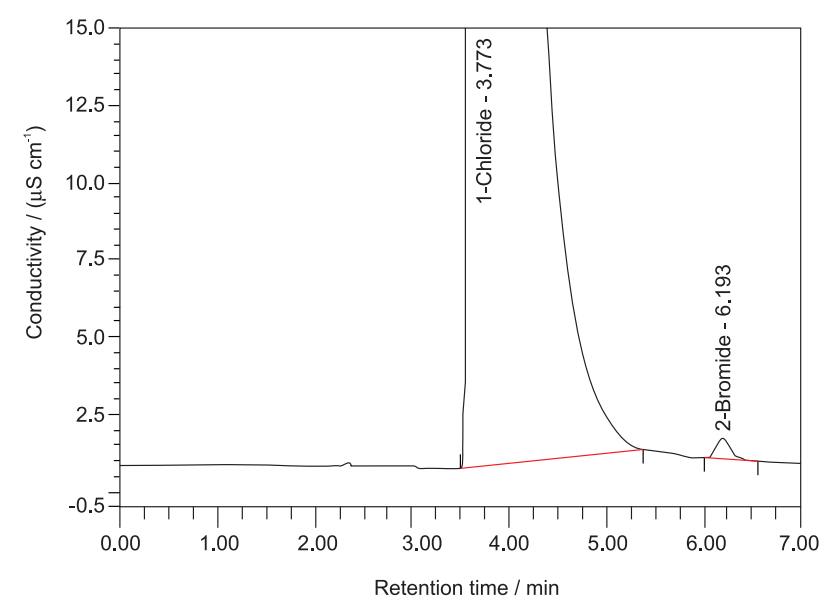

Figure 2. Typical chromatogram obtained from the separation of chloride and bromide in $\mathrm{KCl}$ sample. Mobile phase of $30 \mathrm{mmol} \mathrm{L}^{-1} \mathrm{KOH}$ and flow rate of $1.2 \mathrm{~mL} \mathrm{~min}^{-1}$.

considered to be 3 times the standard deviation (SD) of these replicates. In an analogous approach, the LOQ was considered to be 10 times the SD. ${ }^{28}$ The method accuracy was evaluated by the relative deviation of the measurement from a control solution. The average of bromide mass fraction determined in the sample was $31.32\left(\mathrm{mg} \mathrm{kg}^{-1}\right)$ with expanded uncertainty of $0.41 \mathrm{mg} \mathrm{kg}^{-1}(k=2)$ for a confidence level of approximately $95 \%$.

The uncertainty budget was estimated based on the guides EURACHEM/CITAC ${ }^{29}$ and ISO GUM, ${ }^{30}$ and the sources of uncertainty considered were: the dilution of calibration standards, the repeatability and the calibration curve, as can be seen in Table 2 . The uncertainty associated to the repeatability of measurements was obtained from the standard deviation of the peak areas used to determine the bromide concentration in the samples.

Table 2. Uncertainties considered in the bromide measurements by IC for the CCQM-K48

\begin{tabular}{lc}
\hline \multicolumn{2}{c}{ Uncertainty / $\left(\mathrm{mg} \mathrm{kg}^{-1}\right)$} \\
\hline Associated to standard dilution & 0.004 \\
Associated to repeatability & 0.07 \\
Associated to the calibration curve & 0.13 \\
Combined uncertainty & 0.21 \\
Expanded uncertainty & 0.41 \\
\hline
\end{tabular}

${ }^{\mathrm{a} C o v e r a g e ~ f a c t o r ~} k=2$, for a confidence level of $95 \%$.

One of the main uncertainty sources was the uncertainty associated to the calibration curve, representing the major contribution. This uncertainty is within the expected limits and represents about $0.5 \%$ of the final result. The authors understand that this is almost the possible limit with the approach used.

\section{International comparison CCQM-K48}

With the improvements in the coulometric titration process, and also considering the bromide ion as the main impurity in the $\mathrm{KCl}$ sample, Inmetro has participated in an international key-comparison named as CCQM-K48 for the determination of the purity of $\mathrm{KCl}$. Table 3 shows the results of coulometric titration for $\mathrm{KCl}$ samples. The uncertainty budget of the coulometric titration result ${ }^{2}$ for this comparison is shown in Table 4. According to the data, the main source of uncertainty came from the current.

Table 3. Results of coulometric titration for purity of $\mathrm{KCl}$ in $\mathrm{CCQM}-\mathrm{K} 48^{2}$

\begin{tabular}{lcc}
\hline$n^{\mathrm{a}}$ & Sample weight /g & Amount content $/\left(\mathrm{mol} \mathrm{kg}^{-1}\right)$ \\
\hline 1 & 0.3026985 & 13.41520 \\
2 & 0.3025156 & 13.41180 \\
3 & 0.2998494 & 13.40962 \\
4 & 0.3030152 & 13.41021 \\
5 & 0.3066827 & 13.41109 \\
6 & 0.3055570 & 13.40906 \\
\hline Mean & & 13.41116 \\
Standard deviation & & 0.00221 \\
RSD & & 0.016 \\
\hline
\end{tabular}

${ }^{\mathrm{a}} n$, measurement; ${ }^{\mathrm{b}} \mathrm{RSD}$, relative standard deviation.

The results for bromide with the used measurement methods are shown in Table 5. ${ }^{2}$ The authors believe that even though the results were considered satisfactory by the organizers, they might be a little biased. The main source of bias is believed to be the presence of different chemical species of bromide in the salt. A chemical treatment of the sample may be necessary to determine the total bromine through ion chromatography. One possible change in sample preparation should be the use of more time for it to be equilibrated in solution before analysis. Other approaches should be studied in further works. The uncertainty expanded of $0.41 \mathrm{mg} \mathrm{kg}^{-1}$ is consistent with the repeatability and other uncertainty sources considered in the proposed matrix.

The used reference value in this international comparison, CCQM-K48, was the median of all results submitted by the participating laboratories. The results are shown with bromide correction, since it is the major contaminant in the $\mathrm{KCl}$. The bromide assay was $0.00039 \mathrm{~mol} \mathrm{~kg}^{-1} \pm 1.3 \%$ with coverage factor $(k=2)$, for a confidence level of $95 \%{ }^{2}$ Then, the $\mathrm{KCl}$ purity after bromide correction (determined by Inmetro in this exercise) was $99.9787 \%$, which is equivalent to an amount content of $13.41077 \pm 0.0029 \mathrm{~mol} \mathrm{~kg}^{-1},(k=2)$ for a confidence level of $95 \%$.

There was comparability among the participant metrology institutes, though the result from Inmetro, as 
Table 4. Uncertainty budget for purity of $\mathrm{KCl}$ by coulometry for $\mathrm{CCQM}-\mathrm{K} 48^{2}$

\begin{tabular}{|c|c|c|c|c|c|}
\hline \multirow[t]{2}{*}{ Effect } & \multicolumn{2}{|c|}{ Sensitivity coefficient } & \multicolumn{2}{|c|}{ Uncertainty } & \multirow{2}{*}{$\begin{array}{c}\text { Product } \\
c_{\mathrm{i}} u_{\mathrm{i}} /\left(\mathrm{mol} \mathrm{kg}^{-1}\right)\end{array}$} \\
\hline & $c_{\mathrm{i}}$ & units & $u_{\mathrm{i}}$ & units & \\
\hline Weighing & 44316.7287 & $\mathrm{~mol} \mathrm{~kg}{ }^{-2}$ & $5.50 \times 10^{-10}$ & $\mathrm{~kg}$ & $2.44 \times 10^{-5}$ \\
\hline Buoyancy correction & 13.4005 & mol kg-1 & $2.28 \times 10^{-7}$ & & $3.06 \times 10^{-6}$ \\
\hline Time & 0.0068 & $\mathrm{~mol}(\mathrm{~kg} \mathrm{~s})^{-1}$ & $7.50 \times 10^{-8}$ & $\mathrm{~s}$ & $5.14 \times 10^{-10}$ \\
\hline Current & 66.8490 & $\operatorname{mol}(\mathrm{kg} \mathrm{A})^{-1}$ & $1.70 \times 10^{-5}$ & A & $1.14 \times 10^{-3}$ \\
\hline Faraday constant & 0.0001 & $\mathrm{~mol}^{2}(\mathrm{~kg} \mathrm{C})^{-1}$ & $4.79 \times 10^{-3}$ & $\mathrm{C} \mathrm{mol}^{-1}$ & $6.66 \times 10^{-7}$ \\
\hline End-point-det'n & 1 & & $1.34 \times 10^{-4}$ & mol kg-1 & $1.34 \times 10^{-4}$ \\
\hline Rinse correction & 1 & & $6.71 \times 10^{-5}$ & $\mathrm{~mol} \mathrm{~kg}{ }^{-1}$ & $6.71 \times 10^{-5}$ \\
\hline Current efficiency & 1 & & $8.33 \times 10^{-5}$ & $\mathrm{~mol} \mathrm{~kg}{ }^{-1}$ & $8.33 \times 10^{-5}$ \\
\hline Absorption on $\mathrm{AgCl}$ & 1 & & $3.66 \times 10^{-5}$ & $\mathrm{~mol} \mathrm{~kg}-1$ & $3.66 \times 10^{-5}$ \\
\hline$u_{\mathrm{A}}($ type A uncertainty) & & & & & $0.0009 \mathrm{~mol} \mathrm{~kg}^{-1}$ \\
\hline$u_{\mathrm{B}}$ (type B uncertainty) & & & & & $0.0012 \mathrm{~mol} \mathrm{~kg}^{-1}$ \\
\hline$u_{\mathrm{C}}$ & & & & & $0.0015 \mathrm{~mol} \mathrm{~kg}^{-1}$ \\
\hline$U(k=2 ; 95 \%)^{\mathrm{a}}$ & & & & & $0.0029 \mathrm{~mol} \mathrm{~kg}^{-1}$ \\
\hline
\end{tabular}

${ }^{\mathrm{a}} U$, expanded uncertainty (coverage factor $k=2$ for a confidence level of $95 \%$ ).

Table 5. Results of bromide measurements obtained from participants for CCQM-K48 ${ }^{2}$

\begin{tabular}{|c|c|c|c|c|c|}
\hline \multirow{2}{*}{ Institute } & \multicolumn{4}{|c|}{$\mathrm{Br}$} & \multirow{2}{*}{$\begin{array}{l}\text { Measurement } \\
\text { method }\end{array}$} \\
\hline & Value / $\left(\mathrm{mol} \mathrm{kg}^{-1}\right)$ & Uncertainty / \% & Value / $\left(\mathrm{mg} \mathrm{kg}^{-1}\right)$ & Uncertainty / \% & \\
\hline BAM & 0.00051 & 10 & 41 & 10 & ${\mathrm{ICP}-M S^{\mathrm{a}}}$ \\
\hline Inmetro & 0.00039 & 1.3 & 31.32 & 1.3 & ion chromatography \\
\hline KRISS & 0.000417 & 8 & 33.32 & 8 & ion chromatography \\
\hline NIM & 0.00060 & 11 & 48 & 11 & ICP-MS \\
\hline NIST & 0.00044 & 11 & 35 & 11 & $\mathrm{XRF}^{\mathrm{b}}$ \\
\hline NMIJ & 0.00048 & 1.28 & 38.6 & 1.28 & ion chromatography \\
\hline SMU & 0.00051 & 18 & 40.8 & 18 & ion chromatography \\
\hline Average & 0.00048 & 15 & 38.3 & 15 & \\
\hline
\end{tabular}

aCP-MS = inductively coupled plasma mass spectrometry; ${ }^{\text {XXRF }}$ = X-ray fluorescence; institute/localization: BAM, Germany; Inmetro, Brazil; KRISS, Korea; NIM, China; NIST, The United States of America; NMIJ, Japan and SMU, Slovak.

shown in Figure 3, is somehow lower than the median. These results showed that the measurements carried out by Inmetro needed some improvements. Assays should

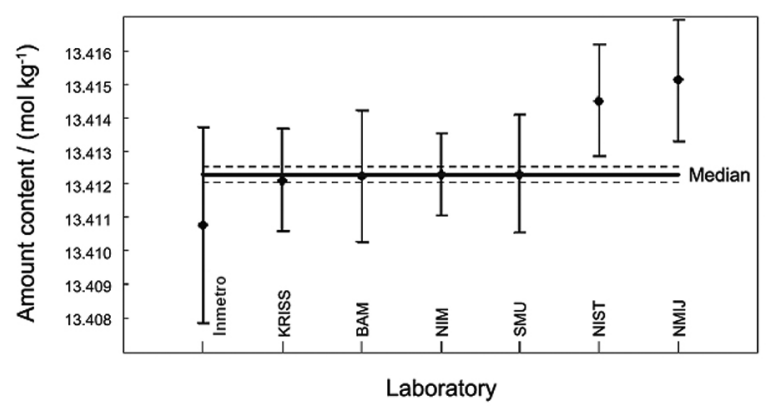

Figure 3. Comparison results of the purity of $\mathrm{KCl}$ for CCQM-K48 with bromide correction. ${ }^{2}$ The error bar means $2 \times u_{\mathrm{c}}\left(u_{\mathrm{c}}\right.$ is the combined uncertainty). be carried out with increased sample weighs to select the best weigh which can reach better current efficiency and, consequently, better accuracy. Another problem could be the co-precipitation/adsorption of the chloride ion on $\mathrm{AgCl}$ precipitated. ${ }^{2}$ In order to avoid this problem, the dissolved $\mathrm{KCl}$ in water should be added gradually into the cell, instead of adding solid $\mathrm{KCl}$ sample at once into the coulometric cell.

\section{Characterization of a candidate CRM}

Table 6 shows the results of the candidate CRM that was assayed by coulometric titration, considering the bromide ion as the main impurity determined by ion chromatography. The mass fraction of the bromide ion in the $\mathrm{KCl}$ sample was $182.47 \mathrm{mg} \mathrm{kg}^{-1}$ with expanded 
Table 6. Coulometric titration results for a candidate CRM of $\mathrm{KCl}$

\begin{tabular}{lccc}
\hline$n^{\mathrm{a}}$ & $\begin{array}{c}\text { Amount content } \\
\text { without Br} \\
\text { correction } /\left(\mathrm{mol} \mathrm{kg}^{-1}\right)\end{array}$ & $\begin{array}{c}\text { Amount content } \\
\text { with Br }\end{array}$ & Purity / \% \\
\hline 1 & 13.40908 & 13.40679 & 99.9494 \\
2 & 13.41118 & 13.40889 & 99.9650 \\
3 & 13.41074 & 13.40845 & 99.9618 \\
4 & 13.41432 & 13.41203 & 99.9884 \\
\hline Mean & 13.41133 & 13.40904 & 99.9662 \\
SD & 0.002 & 0.002 & 0.016 \\
\hline
\end{tabular}

${ }^{\mathrm{a}} n$, number of measurements; ${ }^{\mathrm{b}} \mathrm{SD}$, standard deviation.

uncertainty of $3.03 \mathrm{mg} \mathrm{kg}^{-1}(k=2 ; 95 \%)$. The contribution of the bromide ion in the characterized value by using constant-current coulometric titration was $0.017 \%$. It corresponds to minus $0.0028 \mathrm{~mol} \mathrm{~kg}^{-1}$ on the purity value of the candidate CRM. Therefore, the final value for the characterization of the candidate $\mathrm{CRM}$ of $\mathrm{KCl}$ with its expanded uncertainty was $13.4090 \pm 0.0032 \mathrm{~mol} \mathrm{~kg}^{-1}$ $(k=2 ; 95 \%)$, which corresponds to $99.9662 \%$ in purity.

\section{Conclusions}

The ion chromatographic method was successful for determining bromide as the main impurity in high purity $\mathrm{KCl}$ and all the chromatographic parameters were satisfactory for the analysis on this level.

The characterization results of $\mathrm{KCl}$ primary reference material using coulometric titration with ion chromatography will guarantee Inmetro the competence of measuring amount content with accuracy and reliability which is needed to develop CRM for acid, bases and salts.

After the preliminary studies carried out to characterize the purity of $\mathrm{KCl}$ and also to participate in an international comparison, the value was obtained as amount content (with its expanded uncertainty) of $13.4090 \pm 0.0032 \mathrm{~mol} \mathrm{~kg}^{-1}$ ( $k=2$, considering $95 \%$ of confidence level) which corresponds to $99.9662 \%$ in purity for the characterization of the candidate CRM developed by Inmetro. This candidate CRM, after its certification, can be used to provide quality measurements results with reliability and traceability to the international system of units (SI) when carried out by chemical laboratories in Brazil, mainly those which use titrimetric analysis techniques.

\section{Acknowledgements}

The authors would like to thank the Brazilian Ministry of Science and Technology (MCT) which has provided Inmetro with financial support through the Project
CNPq/Prometro (Conselho Nacional de Desenvolvimento Científico e Tecnológico).

\section{References}

1. Vohra, R. N.; Ghosh, P. K.; Kasundra, A. B.; Joshi, H. L.; Dave, R. H.; Gandhi, M. R.; Langalia, K. J.; Halder, K.; Daga, S. L.; Rathod, R. D.; Deraiya, H. H.; Jadav, P. R.; Mohandas, V. P.; Hamidani Ghosh, A. U.; US pat. 70148322004.

2. Liandi, M.; Mariassy, M.; Pratt, K. W.; Metrologia Tech. Suppl. 2010, 47, 8003.

3. Kaarls, R.; Milton, M. J. T.; C. R. Phys. 2004, 5, 907.

4. Richter, W.; Accred. Qual. Assur. 1997, 2, 354.

5. Mariassy, M.; Vyskocil, L.; Mathiasová, A.; Accred. Qual. Assur. 2000, 5, 437.

6. Harris, D. C.; Análise Química Quantitativa, 7a. ed.; LCT: Rio de Janeiro, RJ, Brasil, 2008.

7. Yoshimori, T.; Talanta 1975, 22, 827.

8. Bishop, E. In Comprehensive Analytical Chemistry; Wilson, C. L.; Wilson D. W., eds.; Elsevier: New York, 1975.

9. Milton, M. J. T.; Quinn, T. J.; Metrologia 2001, 38, 289.

10. Borges, P. P.; Fraga, I. C. S.; Marques, B. S. R.; Dias, J. C.; $O$ Sistema Primário de Coulometria e o seu uso na Certificação de Materias de Referência, in Anais do VII Congresso da Qualidade em Metrologia, São Paulo, Brasil, 2008, available at http://repositorios.inmetro.gov.br/handle/123456789/337 accessed in April 2011.

11. Holler, F. J; Skoog, D. A.; Crouch, S. R.; Princípios de Análise Instrumental, 6a, ed.; Bookman: São Paulo, SP, Brasil, 2009.

12. Felber, H.; Rezzonico, S.; Mariassy, M.; Metrologia 2003, 40, 249.

13. Mariassy, M.; Pratt, K. W.; Spitzer, P.; Metrologia 2009, 46, 199.

14. Merck Certificate of Analysis 1.04936.1000: Potassium Chloride GR for Analysis, Germany.

15. Charles, L. A.; J. Chromatogr., A 1996, 739, 3.

16. Seefeld, S.; Baltensperger, U.; Anal. Chim. Acta 1993, 283, 246.

17. Smith, I. D.; Blackler, P. D.; Waters, D. G.; Anal. Proc. 1993, 30, 372 .

18. Jain, A.; Chaurasia, A.; Sahasrabuddhey, B.; Verma, K. K.; J. Chromatogr., A 1996, 746, 31.

19. Kuldvee, R.; Kaljurand, M.; Smit, H. S.; J. Chromatogr., A 1997, 789, 247.

20. Haddad, P. R.; Anal. Bioanal. Chem. 2004, 379, 341.

21. Silva, R. S.; Carvalho, M. F. B.; Santelli, R. E.; J. Chromatogr., A 2006, 1121, 200.

22. Pratt, K. W.; Anal. Chim. Acta 1994, 289, 135.

23. Ostermann, M.; Berglund, M.; Taylor, P. D. P.; Máriássy, M.; Fresenius J. Anal. Chem. 2001, 371, 721.

24. Asakai, T.; Hara, H.; Murayama, M.; Tanaka, T.; Anal. Sci. 2006, 22, 1121. 
25. NIST Certificate of Analysis SRM 3184: Bromide Anion Standard Solution.

26. NIST Certificate of Analysis SRM 999b: Potassium Chloride (Primary Chemical).

27. Marinenko, G.; Taylor, J. K.; J. Res. Natl. Bur. Stand. 1963, 67A, 31 .

28. DOC-CGCRE-008: Orientação sobre Validação de Métodos Analíticos, Inmetro: Rio de Janeiro, Brasil, 2010, available at http://www.inmetro.gov.br/Sidoq/Arquivos/CGCRE/DOQ/ DOQ-CGCRE-8_03.pdf
29. EURACHEM/CITAC: Quantifying Uncertainty in Analytical Measurements, 2000, available at http://www. measurementuncertainty.org/mu/QUAM2000-1.pdf.

30. Joint Committee for Guides in Metrology; Guia para a Expressão da Incerteza de Medição, 3a., ISO 1995; ABNT, Inmetro: Rio de Janeiro, Brasil, 2003. http://www.inmetro.gov. br/infotec/guia.asp accessed in August 2011.

Submitted: April 7, 2011 Published online: August 4, 2011 